\title{
СТАНОВЛЕННЯ ЯК ФІЛОСОФСЬКЕ ТА ПСИХОЛОГІЧНЕ ПОНЯТТЯ
}

Удк: 159.9:125

\section{Бойко-Бузиль Юлія Юріӥвна}

Кандидат психологічних наук, доцент, докторант кафедри соиіології та психології факультету № 6 Харківського національного університету внутрішніх справ, м. Київ (Україна)

\begin{abstract}
Анотація. В статті представлений теоретичний аналіз категориі «становлення» як філософського та психологічного поняття. 3'ясовано, щзо у філософії «становлення» нероздільно розглядають з «буттям», у психологї - з «розвитком». Однак спільним є беззаперечне визнання існування та иінності «становлення» як індивідуально-особливого феномену та поняття. Виявлено, щуо становлення за своєю суттю є переходом від однієї визначеності буття до іншої; виникненням, утворенням чогось в процесі розвитку; не маючий матеріальних механізмів результат протікання часу в онтогенезі. На основі здійсненого пошукового розгляду спадщини філософської та психолого-педагогічної думки, представлено авторське розуміння становлення як кристалізації (переходу) потенцій (можливостей) в оформлене изіле (акме).
\end{abstract}

Ключові слова: єдине, від'ємне, буття, розвиток, становлення.

Постановка проблеми. В умовах сучасної наукової дійсності особливої актуальності набувають дослідження спадщини філософської та психолого-педагогічної думки, основні положення якої сприяють грунтовному осягненню обраного предмету дослідження як в свідомості так і в практиці. Аналіз поняття становлення представлено у доробках «корифеїв мудрості» 3 метою всеосяжного його аналізу дасть можливість отримати всебічне уявлення про досліджувану філософськопсихологічну категорію.
Відтак, мета статті полягає у здійсненні пошуково-теоретичного аналізу поглядів філософів і психологів на категорію «становлення».

\section{Виклад основного матеріалу дослі-} дження. У філософії «становлення» нероздільно розглядають 3 «буттям». Становлення за своєю суттю є переходом від однієї визначеності буття до іншої. Все існуюче є таким, що становиться, а його буття і є становлення. Будь-яка річ може розглядатися під кутом зору буття та небуття, виникнення або зникнен- 
ня. Становлення - це зміна [14, с. 582], яка за своєю суттю виражає мінливість речей та явищ [35, с. 434], їх перехідний стан [31, с. $513 ; 34$, с. 539], який веде до формування явищ дійсності, пов'язаних 3 перетворенням $[2$, с. 68] від однієї визначеності буття до іншої [13, с. 79], від одного стану до іншого, від одного типу існування до іншого [23, с. 800$]$, від можливості до дійсності [30, с. 87, с. 417; 36 , c. 651$]$.

Некрасова Н. А. та ін. у тематичному філософському словнику, доречно підмічають, що становлення - категорія, що виражає мінливість речей і явищ та використовується в трьох основних значеннях: а) як синонім категорії розвитку; б) як вираження процесу створення передумов процесів та явищ, що виникають на їх основі; в) як характеристика «першопочаткового формування» предмету, як процес, що представляє собою єдність виникнення та знищення, буття та небуття [20, c. 81-82].

Протиставлення становлення буттю як стійкості та незмінності бере свій початок ще в античній філософії. Основоположником концепції становлення був Геракліт. Його розуміння дійсності можливо виразити в формулі «Panta rhei», що перекладається як «Все тече» [1, с. 786]. Категорія становлення органічно пов'язана 3 діалектичним переконанням про світ: в її основу покладено погляд на будь -яку річ, явище, як на єдність протилежностей - буття та небуття [34, с. 539; 35, с. 434]. Ге- ракліт розчиняв буття в становленні та представляв світ як те, що стає, вічно мінливе в цілому [33, с. 977]. Все тече, все змінюється, все проходить та нічого не стоїть на місці. Неможливо двічі війти в одну і ту ж річку. Як уточнює Кратіл, в одну і ту ж річку не можливо увійти навіть жодного разу: поки ти в ню входиш, вона вже стає іншою [14, с. 582].

Парменід, навпаки, вважав становлення таким, що здається та істинне існування приписував тільки буттю [33, с. 977]. Оскільки буття - це все, що є, що існує. Протилежність йому - небуття, тобто все те, чого не існує. I якщо в небутті нічого не існує, значить, що небуття не існує, тобто є тільки буття. Становлення виступає лише якістю буття. Бо те, що з'являється на світ, виникає або 3 буття, або $з$ небуття. Якщо воно виникає 3 першого, значить, воно вже існувало, а якщо 3 останнього - значить, це ніщо, бо із «нічого» нічого не виникає. Становлення - це ілюзія. Буття просто $є$ і воно єдине, оскільки множинність - теж ілюзія [11, с. 59].

Діалектичний зміст категорії становлення детально розвив Гегель. В його філософiї категорія становлення виступає в якості «першої істини», що складає «стихію» всього наступного розвитку логічних визначень ідеї (категорії) [35, с. 434]. До руху становлення від ніщо до буття (становлення) і від буття до ніщо (приходження) неможлива жодна думка [32, с. 256]. Становлення як рух та зміна [32, с. 39] є іманентним синтезом буття та ніщо [7, 
c. 155], хитким неспокоєм, що осідає, переходячи в деякий спокійний результат [16, с. 236] та представляє собою абстрактне вираження виникнення, породження речей та явищ: не існує нічого такого, «що не було б середнім станом між буттям та ніщо». Тобто, перше переходить у «друге» та «друге» в «перше» [14, с. 582]. Ось чому «становлення» - перше конкретне вираження думки (тоді як «буття» і «ніщо» по-суть пусті абстракції), а відповідно, і «первинна» істина. Гегель вірний Геракліту та реальності: істинне $\epsilon$ те, що $є$ становлення самого себе. Саме в становленні одиничні емпіричні явища знаходять свою кінцеву природу [32, с. 39].

В онтології Платона становлення - це визначення, що дається процесу народження та смерті, замкнутому в коло становлення [24, c. 538]. Становлення - це те, що невловиме, не піддається твердій фіксації, що вислизає, змінюється на очах, постає «як то м'яке, то як тверде», про що неможливо висловити нічого конкретного. Для того, щоб стало можливим зупинити цей потік, виокремити в щось одне, відрізнити його від іншого, виміряти його в якому-небудь відношенні, необхідна якась інша реальність, яка б дозволила би здійснити стосовно до неї подібні процедури. Або, необхідно допустити таку реальність, яка б була умовою можливості здійснення цих операцій. Саме цю реальність Платон називає буттям [6, c. 120]. Речі, які становляться завжди виникають і ніколи не існують, тому що їх наукове пізнання неможливе і доводиться задовольнятися думкою або міфом відносно них [24, с. 539]. Вічно існуючий розумоосягаючий світ ідей є парадигмою для чуттєво світу, що повсякчас сприймається та який вічно стає [33, с. 977]. Становлення є чимось змішаним з межі та безмежного [24, с. 183]. Для Платона «єдине» трансцендентне, тому становлення не заперечується, а належить до створеного світу. Становлення так же схоже на буття, як віра на істину [11, с. 286]. Філософ принципово протиставляв суще, буття, та зміни, становлення [41, с. 332] і наполягав, що становлення $\epsilon$ зображенням сутності, остання ж володіє виходом за свої межі, який узгоджується 3 зверхсутнісною єдністю [24, с. 445]. На питання, який саме процес повинен відбуватися, щоб здійснилось становлення, Платон відповідав, що це можливо лише тоді, коли існує деякий початок і він зазнає зростання і так досягає другого розвитку, а відштовхуючись від нього - наступного, і коли, досягнувши третього, він може бути сприйнятий тими, кому притаманне сприйняття. Шляхом такої зміни і такого переходу виникає все, і воно має дійсне буття, оскільки залишається таким; та переходячи в інший стан, воно повністю зникає [28, с. 183].

Аристотель, який відмовився від буття в формі особливого світу ідей, надав становленню характеристику спрямованості через ентелехію [36, с. 651]. Джерелом та одночасно ціллю будь-якого становлення став Бог. Опис 
світу як становлення почав передбачати особливу систему категорій, яка відрізняється від тієї, на якій грунтується опис світу як буття $[37$, с. 436]. Становлення описується в координатах абсолютних категорій, в той час, як буття потребує для свого опису порівняльних категорій. Якщо процес становлення викликається тим, що має виникнути, то спрямовується - ціллю. Завдяки ентелехії (діяльний, активний, формувальний початок) ціль може міститися в тому, хто становиться. Становлення існує як реалізація однієї з можливостей, яка будучи реалізованою виключає інші можливості, але тільки в дійсності, а не в можливості. Якщо актуалізована можливість знову стане просто можливістю, то іiї змінить інша актуалізована можливість [41, с. 426]. Аристотель писав, що «ніяке становлення не має нічого спільного з цілями, як будівництво будинку не має нічого спільного з самим будинком» [10, c. 30].

Матеріалістична діалектика К. Г. Маркса розуміє під становленням момент всякого розвитку і відповідно ототожнює становлення 3 розвитком [36, с. 651]. Коли явище вже виникає, але ще не досягло повного здійснення його існування неможливо вважати завершеним, однак, почавшись, воно вже є. Становлення характеризує процес зародження можливостей та перетворення їх в дійсність. Становлення як єдність буття та ніщо виражає всезагальну боротьбу виникнення, існування, згасання та зникнення будь-яких речей та явищ [1, с. 787].

У філософії життя О. Шпенглера, життя має сенс, близький до поняття становлення, тому основне, що привертає увагу філософа, це саме становлення та «ставше». Становлення та «ставше» - це факт та предмет життя [18, с. 331]. Життя у О. Шпенглера є первинним початком, яке лежить в основі всього буття. Законом цього первинного початку є доля [18, c. 332].

Разом 3 поняттями зміни, виникнення, перетворення, оновлення, формування, відтворення поняття становлення входить в склад визначень, які характеризують більш широкі поняття буття, руху, процесу. Становлення фіксує деяку парадоксальність буття - річ (організм, подія, ідея) вже визначилась, але іiі ще не існує; iї ще не має, але вона вже здійснює вплив на оточуюче середовище, змінює сукупність умов та протікання подій. Парадоксальність становлення призводить це поняття в ранг характеристик людського буття, його єдності та різноманітності, його проблемності та суперечливості [31, с. 513].

С. О. Дружілов доцільно стверджує, що становлення розкривається як філософська категорія буття, яка виражає оформлення явищ, набуття ними нових ознак. 3 одного боку, становлення - це ще не буття того, що в процесі становлення, а тільки рух до буття. 3 другого боку, становлення - це актуалізація того, що вже в тій чи іншій формі існує, оскільки ніщо не може виникнути 3 неіснуючого 
[9, c. 119].

А. Н. Уайтхвд у своїй найбільш відомій метафізичній роботі «Процес та реальність» визначив принципи становлення. «Принцип процесу» встановлює, що дійсність є становленням. «Принцип відносності» вказує на місце об'єкта в цьому процесі, тобто будь-яка об'єктивність є можливістю для становлення. Таким чином, становлення $є$ перетворенням можливості в дійсність. Природу цього перетворення розкриває «реформований суб'єктивістський принцип», згідно до якого, становлення є становленням суб'єктивної єдності, яка вбирає в себе об'єктивну даність. Цей акт асиміляції об'єктивних даних і «стягування» їх в об’єктивну єдність «досвіду», філософ позначає спеціальним терміном «претензія» (prehension) - «схоплювання». Інколи він користується в якості синоніма слово «почуття», яке може бути двох типів «фізичне» (якщо його об'єкт представляє собою стійкий елемент дійсності) або «концептуальне» (коли воно спрямоване на «вічний об’єкт»). Таким чином, не тільки можливість перетворюється в дійсність, але i дійсність стає можливістю, об'єктивною даністю для нового становлення, як тільки завершить процес самоформування. В даному випадку подія втрачає свою суб'єктивну єдність та стає будівельним матеріалом для нового «дійсного існування» або «дійсної події» [30, c. 417].

Становлення виявляє таку сторону ру- ху, як невпинність, динамічність, процесуальність змін, що охоплюють увесь світ. У становленні світ постійно є чимось, чим він не $є$ зараз, але при цьому залишається тим же самим, що був завжди [22, с. 58]. Становлення відображає об'єктивний процес перетворення нового предмета або явища з реальної можливості у дійсність та виражає раптову мінливість речей і явищ, їхнє неперервне перетворення 3 однієї властивості в іншу. Усе, що існує, перебуває у становленні, а його буття і $\epsilon$ цим процесом [13, с. 79].

Ми переконані, що буття - це об'єктивно існуюча реальність, а становлення - перетворена в дійсність незавершена можливість буття, де внутрішньою метою руху виступає сама потенція. При чому, потенція (від лат. potentia - сила) [29, Т. 7. с. 403] - це приховані можливості, здатності, сили для якої-небудь діяльності, що можуть виявитися за певних умов. Бути у (в) потенції - бути в прихованому стані, не дістаючи зовнішнього вияву, застосування, втілення в життя.

Становлення також доцільно розглядати у тандемі з деградацією [39, с. 608]. Становлення і деградація - категорії, що характеризують процеси набуття (становлення) чи втрати (деградація) завершеної форми. Дані поняття поєднують моменти виникнення і зникнення речей, зародження можливостей і їх перетворення в дійсність або втрачання. Недарма, в словнику української мови вказано, що становлення - це процес виникнення, утворення 
чого-небудь у сукупності характерних ознак i форм [29, Т. 9. с. 649], а деградація - поступове погіршання, втрата якихось якостей, властивостей; занепад, виродження [29, Т. 2. c. 230].

Хід процесів становлення і деградації залежить від багатьох факторів і позначається на проміжних формах їх реалізації, набуваючи характеру прогресу чи регресу, еволюції чи інволюції, стійкого стану або коливальних рухів, розпаду і зникнення деградацією [39, c. 608]. Суперечлива єдність становлення і деградації добре відбивається в понятті кенозису для позначення сходження Бога в світ, творення світу і одночасно спустошення, тобто вичерпання. В сучасній філософії подібна суперечність відбивається, зокрема, в понятті феноменологічної редукції, яке означає очищення, повернення назад, зведення одного явища до іншого з метою їх спрощення [38, с. 383], тобто збіднення Я від будь-яких психічних феноменів і натуралістичних уявлень, але в той же час - це рух до чистого (трансцендентального) Я.

Стає зрозумілим, що становлення не завжди має та і не обов'язково повинно мати успішний результат. Становлення може спотворюватися як внутрішніми так і зовнішніми чинниками. Потенція як ціль становлення може самовичерпатися або змінитися в самому зародку. Так само об'єктивні обставини, так би мовити реальне буття, ладне трансформувати одну потенцію в іншу, і таким чином знищити необхідність становлення першої.

Цілком зрозуміло, що наш вектор наукового пошуку більше орієнтований на психологічне розуміння «становлення», яке безпосередньо у психології, нероздільно пов'язане 3 поняттям «розвитку», зокрема особистості. У зв'язку з цим виникає обгрунтована необхідність з'ясувати, чим «становлення» різниться від «розвитку».

Взагалі, розвиток - це 1) процес переходу з одного стану в інший, більш досконалий, перехід від старого якісного стану до нового якісного стану, від простого до складного, від нижчого до вищого; 2) ступінь свідомості, освіченості, культурності [1, с. 702;9, c. $119 ; 15$, c. $55 ; 21$, c. $632 ; 37$, c. $382 ; 27$, c. $159 ; 20$, с. 79-80]. А становлення - це виникнення, утворення чогось в процесі розвитку $[21$, с. 749$]$, не маючий матеріальних механізмів результат протікання часу [40, с. 232] в онтогенезі [4, с. 28].

У підручнику з вікової психології за редакцією Г. С. Костюка вказано, що розвиток - це зміни живої людської системи, зміни не випадкові, а необхідні, послідовні, пов'язані з певними етапами іiі життєвого шляху, i прогресивні, тобто такі, що характеризують їі рух від нижчих до вищих рівнів життедіяльності, іiі структурне й функціональне вдосконалення. Розвиток - це безперервний процес, що виявляється у кількісних змінах людської істоти, тобто збільшенні одних і зменшені інших іiї ознак (фізичних, фізіологічних, психіч- 
них). Але він не зводиться до кількісних змін, до зростання того, що вже $\epsilon$, а включає «перерви безперервності», тобто якісні зміни. Кількісні зміни зумовлюють виникнення нових якостей, тобто ознак, властивостей, які утворюються в ході самого розвитку, і зникнення старих. Розвиток є там, де народжується щось нове і водночас відживає старе [4, с. 28]. Саме в останні тезі чітко прослідковується зв'язок розвитку зі становленням.

В практичному словнику синонімів української мови С. Й. Караванського:

Розвиток - розвій, /роз/ріст, процес росту, (буйний) розмах, розквіт, процвітання; ФР. рух, хід, поступ; (чий) освіченість, рівень; розвинення, розвивання. Розвиватися - перебувати в розвитку, не зупинятися на досягнутому, розбудовуватися, зростати, відбуватися, міцніти, набирати сил, прогресувати, розгортатися, розкручуватися, розмотуватися, розплітатися; П. перебувати в розвитку; (фірму) розбудовуватися; (дітей) рости, зростати; (події) відбуватися; (рух) набирати сил, міцніти; (економіку) прогресувати, г. поступати, о. пишним цвітом процвітати; (бруньки) розбруньковуватися, розпускатися [12, с. 387].

Становлення - (ідеї) постання, вироблення, розбудова (держави). Становити, (на ноги тощо) ставити; (рекорд) установляти; (виняток) являти собою, бути чим; (себе) Д. виставляти; (частку цілого) р. складати. Становище, (тяжке) обставини, умови, умовний; (на війні) ситуація; пат; (чиє) роль, місце; (воєнне) стан, режим; (своє) позиція, точка зору; (до чого) ставлення [12, с. 435].

$\mathrm{У}$ психологічних словниках становлення визначається як процес розвитку, у якому індивід перебирає на себе відповідальність за максимально повну реалізацію свого потенціалу $[5$, с. $210 ; 8$, с. $40 ; 25$, с. $467 ; 26$, с. 521$]$. Паралельно, індивідуальний розвиток розглядається як: 1) послідовність змін протягом тривалості життя організму від народження до смерті; 2) дозрівання як біологічний процес обумовлений генетичними процесами, оскільки значення етимологічно походить від старофранцузького «desveloper» та означає розкриття і розгортання; 3) незворотна послідовність змін, що передбачає проходження одна за одною стадій; 4) прогресивна зміна, яка веде до більш високого рівня диференціації та організації, що передбачає позитивний характер прогресу, збільшення ефективності функціонування, дозрівання, покращення, збагачення та ускладнення [3, с. 163].

Є. Е. Крігер вважає, що в категорію становлення входять наступні три процеси розвитку особистості: 1) соціальний аспект, пов'язаний з засвоєнням соціального досвіду та входженням в соціальне середовище; 2) індивідуальний аспект як формування індивідуально-типологічних особливостей людини на основі природних задатків, соціальних умов та культури; 3 ) персоналізація, пов'язана 3 формуванням самої особистості [17, с. 241-242].

Отже, розвиток - це поступальний рух 
чого-небудь 3 подальшим його вдосконаленням, при якому це будь-що набуває сили та міцності. Становлення - це кристалізація, виникнення чого-небудь 3 подальшим його укоріненням, при якому це будь-що набуває вигляду та форми, тобто оформленого цілого, що в найкращому своєму вияві стає акме. Де, кристалізація - це: 1) перехід речовини з аморфного стану в кристалічний; 2) у переносному значенні - становлення, набуття чітких форм [29, Т. 4. с. 349]; акме (від грец. akme найвища степінь, вершина) - це найвища точка в розвитку, зокрема особистості [19, с. 35].

Ми вважаємо, що становлення є від'ємною категорією від розвитку, які мають досить схожі підвалини, але є абсолютно різними в своєму автентичному розумінні. Розвиток $є$ продовженням становлення, оскільки як можна розвиватися не виникнувши, не з'явившись, тобто не ставши. Становлення є першою сходинкою утворення будь-якого психологічного явища, є процесом появи феномену, рухом вдосконалення. Спочатку відбувається становлення, яке через певний час трансформується в розвиток. Становлення започатковує психологічне явище, укріплює його, закладає основи, є немов би фундаментом, внутрішнім джерелом. А розвиток підхоплює дану хвилю та поступово насичує, удосконалює психологічне явище.

Враховуючи все вище зазначене, нами були сформульовані суттєві відмінності розвитку і становлення:
1) розвиток - це процес удосконалення, як перехідна послідовність від старого якісного стану до нового якісного стану; а становлення - це складна система, як множина взаємопов'язаних можливостей, які утворюють єдине ціле та взаємодіють між собою та з зовнішнім світом;

2) розвиток спрямований на підвищення наявного (вже сформованого) рівня можливостей, від нижчого до вищого; а становлення спрямоване на безпосередній розвиток самих можливостей (потенцій);

3) розвиток має мету, оскільки є цілеспрямованим рухом вперед; становлення має лише кінцевий результат, оскільки становлення відбувається заради становлення;

4) розвиток має якісний показник свого прояву (високий або низький, прогрес або регрес); а становлення має кількісну міру вияву ( $є$ або не існує, становлення або деградація);

5) розвиток можливо контролювати та направляти (ставити конкретну ціль і спеціально організованими заходами іiі досягати); а становлення супроводжувати і забезпечувати (бачити можливу ціль, тобто потенцію та сприяти її досягненню).

Відтак, ми переконані, що «становлення» - це кристалізація (перехід) потенцій (можливостей) в оформлене ціле (акме).

Висновки. Філософське та психологічне розуміння становлення різняться за своєю суттю. У філософії становлення нероздільно 
розглядають 3 «буттям», в психології - 3 «розвитком». Однак спільним є беззаперечне визнання існування та цінності «становлення» як індивідуально-особливого феномену та поняття.

\section{Перспективи подальших розвідок у} даному напрямі вбачаємо в обгрунтуванні власної концепції становлення.

\section{Перелік використаних джерел:}

1. Андрущенко И. В. Философский словарь / И. В. Андрущенко, О. А. Вусатюк, С. В. Линецкий, А. В. Шуба. K.: «A.C.K.», 2006. - 1056 c.

2. Батаршев A. В. Моделирование профессиональноличностного становления и развития педагога профессиональной школы / А. В. Батаршев // Педагогика. 2014. - № 8. - С. 68-77.

3. Большой толковый психологический словарь. Т. 2 (ПЯ); Пер с англ. / Ребер Артур. ООО «Издательство АСТ»; «Издательство «Вече», 2003. - 560 с.

4. Вікова психологія: навчальний посібник / За ред. Г.

С. Костюка. - К.: Радянська школа, 1976. - 269 с.

5. Военно-психологический словарь-справочник / Под общ. ред. Ю. П. Зинченко. - М.: ИД Куприянова / Общество психологов силовых структур, 2010. - 592 с.

6. Гайденко П. П. Обоснование научного знания в философии Платона / П. П. Гайденко // Платон и его эпоха. - М.: Наука, 1979. С. 99-14.

7. Гегель Г. В. Ф. Наука логики / Пер. с нем. Б. Г. Столпнера. - М.: Мысль, 1970. - Т. 1. - 500 с.

8. Глоссарий по психологии профессионального развития / Сост. А. М. Павлова, О. А. Рудей, Н. О. Садовникова; / Под общ. ред. Э. Ф. Зеера. Екатеринбург: Изд-во Рос. гос. проф.-пед. ун-та, 2006. - 62 с.

9. Дружилов C. А. Становление профессионализма как процесс профессионального развития человека и личностное здоровье как его ресурс / С. А. Дружи- лов // Международный журнал экспериментального образования. - 2013. - № 10. - Ч. 1. - С. 118-120.

10. Зубов В. П. Аристотель: монография / В. П. Зубов / Акад. наук СССР. - М.: Акад. наук СССР,1963. - 364 с. 11. История философии. Древняя Греция и Древний Рим. Т. І. / Пер. с англ. Ю. А. Алакина. - М.: Центрполиграф, 2003. - 335 с.

12. Караванський С. Й. Практичний словник синонімів української мови / С. Й. Караванський. - 5-те вид., опрац. і допов. - Л.: БаК, 2014. - 530 с.

13. Козирєв М. П. Професійне становлення студента в умовах вищого навчального закладу / М. П. Козирєв // Науковий вісник ЛДУВС. Серія психологічна. - Львів: ЛьвДУВС, 2015. - Вип. 1. - С. 78-89.

14. Конт-Спонвиль А. Философский словарь / Пер. с фр. Е. В. Головиной. - М.: Этерна, 2012. - 752 с.

15. Краснобокий Ю. М. Словник-довідник науковцяпочатківця / Ю. М. Краснобокий, К. М. Левківський. / МОН України. Науково-методичний центр вищої освіти. - 2-ге вид, випр. і доп. - К.: НМЦВО, 2001. - 71 с.

16. Кривуля О. М. Філософія: Навчальний посібник / О. М. Кривуля. - Х.: ХНУ імені В. Н. Каразіна, 2010. - 592 c.

17. Кригер Е. Э. Особенности профессионального становления педагога / Е. Э. Кригер // Психологическая наука и образование. 2013. - №4. - С. 241-249. - Режим доступу: http://psyedu.ru/journal/2013/4/Kriger.phtml 18. Лега В. П. История западной философии. Часть вторая. Новое время. Современная западная философия: учеб. пособие / В. П. Лега. - 2-е изд., доп. и перераб. М.: Изд-во ПСТГУ, 2009. - 456 с.

19. Мещееяков Б. Г. Большой психологический словарь / Б. Г. Мещеряков, В. П. Зинченко. - АСТ; АСТМосква; Прайм-Еврознак; Москва; СПб, 2008. - 868 с.

20. Некрасова Н. А. Тематический философский словарь: Учебное пособие / Н. А. Некрасова, С. И. Некрасов, О. Г. Садикова. - М.: МГУ ПС (МИИТ), 2009. - 164 с.

21. Ожегов С. И. Словарь русского языка: около 60000 сл. и фразеологических выражений / Общ. ред. Л. И. Скворцов. - 25-е изд., испр. и доп. - М.: ОНИКС: Мир 
и Образование, 2006. - 973 с.

22. П'янзін С. Д. Філософська пропедевтика: навч.метод. посіб. / С. Д. П'янзін. - Черкаси: ЧНУ ім. Б. Хмельницького, 2016. - 108 с.

23. Постмодернизм: энциклопедия / Сост. и науч. ред.: А. А. Грицанов, М. А. Можейко. - Минск: Интерпрессервис: Кн. дом, 2001. - 1038 с.

24. Прокл, Платоновская теология / Пер. с древнегреч., сост., статья, примечания, указатели, словарь Л. Ю. Лукомского. - СПб: РХГИ; «Летний сад», 2001. - 624 с. 25. Психологический словарь / Авт.-сос. В. Н. Копорулина, М. Н. Смирнова, Н. О. Гордеева, Л. М. Балабанова; / Под. об. ред. Ю. Л. Неймера. - Р.-на-Д.: Феникс, 2003. -640 c.

26. Психологічний тлумачний словник найсучасніших термінів: близько 3000 слів / В.О. Олефир [та ін.]; ред. В.Б. Шапар. - Х.: Прапор, 2009. - 672 с.

27. Психологія: терміни, поняття, визначення: словникдовідник / За заг. ред. Г. В. Ложкіна. - Луцьк: ВНУ ім. Л. України, 2011. - 188 с.

28. Слезак T. А. Как читать Платона / Пер. с нем., предисл. и примеч. М. Е. Буланенко. - СПб: Изд-во СПб ун -та, 2008. - 314 c.

29. Словник української мови: в 11 т. / АН УРСР, Інститут мовознавства ім. О. О. Потебні; редкол.: І. К. Білодід та ін. - К.: Наукова думка. - Т. 2. 1972. 552 с.; - Т. 4. 1973. 840 c.; - T. 7. 1976.723 c.; - T. 9. 1978. - 920 c. Режим доступу: http://sum.in.ua/

30. Современная западная философия: Словарь / Сост. и отв. ред. В. С. Малахов, В. П. Филатов. - 2-е изд., перераб. и доп. - М.: ТОН-Острожье, 1998. - 544 с.

31. Современный философский словарь / Ред. В. Е. Кемеров. - М.; Бишкек; Екатеринбург: Одиссей, 1996. $607 \mathrm{c}$.

32. Судьбы гегельянства: философия, религия и политика прощаются с модерном / Под ред. Козловски П. и Соловьева Э. Ю.; Пер. с нем. А. В. Кричевского, П. П. Гайденко, Е. Л. Петренко. - М.: Республика, 2000. - 383 c.

33. Философия: Энциклопедический словарь / Под ред.
А. А. Ивина. - М: Гардарики, 2004. - 1072 с.

34. Философский словарь / Под ред. И. Т. Фролова. - 7е изд., перераб. и доп. - М.: Республика, 2001. - 719 с. 35. Философский словарь / Под ред. М. М. Розенталя, П. Ф. Юдина. - М.: Политиздат, 1963. - 544 с.

36. Философский энциклопедический словарь / Ред. Л. Ф. Ильичев, П. Н. Федосеев, С. М. Ковалев. - М.: Советская Энциклопедия, 1983. - 840 с.

37. Философский энциклопедический словарь / сост. Е. Ф. Губский, Г. В. Кораблева, В. А. Лутченко. - М.: ИНФРА-М, 2000. - 576 c.

38. Філософія: мислителі, ідеї, концепції: Підручник / В. Г. Кремень, В. В. Ільїн. - К.: Книга, 2005. - 528 с.

39. Філософський енциклопедичний словник / НАН України, Ін-т філософії ім. Г. С. Сковороди; редкол.: В. I. Шинкарук (голова). - К.: Абрис, 2002. - 742 с. 40. Хасанов И. А. Время как объективно-субъективный феномен: словарь / И. А. Хасанов. - М.: ПрогрессТрадиция, 2011. - 328 с.

41. Чанышев А. Н. Философия Древнего мира: Учеб. для вузов / А. Н. Чанышев. - М.: Высшая шкока, 1999. $703 \mathrm{c.}$

\section{References (Transliteration):}

1. Andruschenko I. V. Filosofskiy slovar / I. V. Andruschenko, O. A. Vusatyuk, S. V. Linetskiy, A. V. Shuba. K.: «A.S.K.», 2006. - 1056 s.

2.Batarshev A. V. Modelirovanie professionalnolichnostnogo stanovleniya i razvitiya pedagoga professionalnoy shkolyi / A. V. Batarshev // Pedagogika. - 2014. № 8. - S. 68-77.

3. Bolshoy tolkovyiy psihologicheskiy slovar. T. 2 (P-Ya); Per s angl. / Reber Artur. OOO «Izdatelstvo AST»; «Izdatelstvo «Veche», 2003. - 560 s.

4. Vikova psihologIiya: navchalniy posibnik / Za red. G. S. Kostyuka. - K.: Radyanska shkola, 1976. - 269 s.

5. Voenno-psihologicheskiy slovar-spravochnik / Pod obsch. red. Yu. P. Zinchenko. -M.: ID Kupriyanova / Obschestvo psihologov silovyih struktur, 2010. - 592 s. 
6. Gaydenko P. P. Obosnovanie nauchnogo znaniya v filosofii Platona / P. P. Gaydenko // Platon i ego epoha. - M.: Nauka, 1979. S. 99-14.

7. Gegel G. V. F. Nauka logiki / Per. s nem. B. G. Stolpnera. - M.: Myisl, 1970. - T. 1. - 500 s.

8. Glossariy po psihologii professionalnogo razvitiya / Sost. A. M. Pavlova, O. A. Rudey, N. O. Sadovnikova; / Pod obsch. red. E. F. Zeera. Ekaterinburg: Izd-vo Ros. gos. prof. -ped. un-ta, 2006. - 62 s.

9. Druzhilov S. A. Stanovlenie professionalizma kak protsess professionalnogo razvitiya cheloveka i lichnostnoe zdorove kak ego resurs / S. A. Druzhilov // Mezhdunarodnyiy zhurnal eksperimentalnogo obrazovaniya. - 2013. - № 10. - Ch. 1. - S. 118-120.

10. Zubov V. P. Aristotel: monografiya / V. P. Zubov / Akad. nauk SSSR. - M.: Akad. nauk SSSR,1963. - 364 s.

11. Istoriya filosofii. Drevnyaya Gretsiya i Drevniy Rim. T.

I. / Per. s angl. Yu. A. Alakina. - M.: Tsentrpoligraf, 2003. $-335 \mathrm{~s}$.

12. Karavanskiy S. $Y$. Praktichniy slovnik sinonimiv ukrayinskoyi movi / S. Y. Karavanskiy. - 5-te vid., oprats. I dopov. - L.: BaK, 2014. - $530 \mathrm{~s}$.

13. Kozirev M. P. Profeslyne stanovlennya studenta v umovah vischogo navchalnogo zakladu / M. P. KozirEv // Naukoviy visnik LDUVS. SerIya psihologichna. - Lviv: LvDUVS, 2015. - Vip. 1. - S. 78-89.

14. Kont-Sponvil A. Filosofskiy slovar/Per. s fr. E. V. Golovinoy. - M.: Eterna, 2012. - 752 s.

15. Krasnobokiy Yu. M. Slovnik-dovidnik naukovtsyapochatkivtsya / Yu. M. Krasnobokiy, K. M. Levkivskiy. / MON UkraYini. Naukovo-metodichniy tsentr vischoYi osvIti. - 2-ge vid, vipr. I dop. - K.: NMTsVO, 2001. - 71 s. 16. Krivulya O. M. Filosofiya: Navchalniy posibnik / O. M. Krivulya. - H.: HNU Imeni V. N. KarazIna, 2010. - 592 s. 17. Kriger E. E. Osobennosti professionalnogo stanovleniya pedagoga / E. E. Kriger // Psihologicheskaya nauka i obrazovanie. 2013. - № 4. - S. 241-249. - Rezhim dostupu: http://psyedu.ru/journal/2013/4/Kriger.phtml

18. Lega $V$. P. Istoriya zapadnoy filosofii. Chast vtoraya. Novoe vremya. Sovremennaya zapadnaya filosofiya: ucheb. posobie / V. P. Lega. - 2-e izd., dop. i pererab. - M.: Izd-vo PSTGU, 2009. - $456 \mathrm{~s}$.

19. Mescheryakov B. G. Bolshoy psihologicheskiy slovar / B. G. Mescheryakov, V. P. Zinchenko. - AST; ASTMoskva; Praym-Evroznak; Moskva; SPb, 2008. - 868 s.

20. Nekrasova N. A. Tematicheskiy filosofskiy slovar: Uchebnoe posobie / N. A. Nekrasova, S. I. Nekrasov, O. G. Sadikova. - M.: MGU PS (MIIT), 2009. - 164 s.

21. Ozhegov S. I. Slovar russkogo yazyika: okolo $60000 \mathrm{sl}$. i frazeologicheskih vyirazheniy / Obsch. red. L. I. Skvortsov. - 25-e izd., ispr. i dop. - M.: ONIKS: Mir i Obrazovanie, 2006. $-973 \mathrm{~s}$.

22. P'yanzIn S. D. FIlosofska propedevtika: navch.-metod. posIb. / S. D. P'yanzIn. - Cherkasi: ChNU Im. B. Hmelnitskogo, 2016. - $108 \mathrm{~s}$.

23. Postmodernizm: entsiklopediya / Sost. i nauch. red.: A. A. Gritsanov, M. A. Mozheyko. - Minsk: Interpresservis: Kn. dom, 2001. - $1038 \mathrm{~s}$.

24. Prokl Platonovskaya teologiya / Per. s drevnegrech., sost., statya, primechaniya, ukazateli, slovar L. Yu. Lukomskogo. - SPb: RHGI; «Letniy sad», 2001. - 624 s. 25. Psihologicheskiy slovar / Avt.-sos. V. N. Koporulina, M. N. Smirnova, N. O. Gordeeva, L. M. Balabanova; / Pod. ob. red. Yu. L. Neymera. - R.-na-D.: Feniks, 2003. - 640 s. 26. PsihologIchniy tlumachniy slovnik naysuchasnishih terminiv: blizko 3000 sliv / V.O. Olefir [ta In.]; red. V.B. Shapar. - H.: Prapor, 2009. - 672 s.

27. PsihologIya: termIni, ponyattya, viznachennya: slovnikdovidnik / Za zag. red. G. V. LozhkIna. - Lutsk: VNU Im. L. UkraYini, 2011. - $188 \mathrm{~s}$.

28. Slezak T. A. Kak chitat Platona / Per. s nem., predisl. i primech. M. E. Bulanenko. - SPb: Izd-vo SPb un-ta, 2008. $-314 \mathrm{~s}$.

29. Slovnik ukrayinskoyi movi: v 11 t. / AN URSR, Institut movoznavstva Im. O. O. PotebnI; redkol.: I. K. BIlodId ta In. - K.: Naukova dumka. - T. 2. 1972. 552 s.; - T. 4. 1973. 840 s.; - T. 7. 1976. 723 s.; - T. 9. 1978. - 920 s. - Rezhim dostupu: http://sum.in.ua/

30. Sovremennaya zapadnaya filosofiya: Slovar / Sost. i otv. red. V. S. Malahov, V. P. Filatov. - 2-e izd., pererab. i 
dop. - M.: TON-Ostrozhe, 1998. - $544 \mathrm{~s}$.

31. Sovremennyiy filosofskiy slovar / Red. V. E. Kemerov. - M.; Bishkek; Ekaterinburg: Odissey, 1996. - 607 s.

32. Sudbyi gegelyanstva: filosofiya, religiya i politika proschayutsya s modernom / Pod red. Kozlovski P. i Soloveva E. Yu.; Per. s nem. A. V. Krichevskogo, P. P. Gaydenko, E.

L. Petrenko. - M.: Respublika, 2000. - 383 s.

33. Filosofiya: Entsiklopedicheskiy slovar/ Pod red. A. A. Ivina. - M: Gardariki, 2004. - 1072 s.

34. Filosofskiy slovar / Pod red. I. T. Frolova. - 7-e izd., pererab. i dop. - M.: Respublika, 2001. - 719 s.

35. Filosofskiy slovar / Pod red. M. M. Rozentalya, P. F. Yudina. - M.: Politizdat, 1963. - 544 s.

36. Filosofskiy entsiklopedicheskiy slovar / Red. L. F. Ilichev, P. N. Fedoseev, S. M. Kovalev. - M.: Sovetskaya Entsiklopediya, 1983. - $840 \mathrm{~s}$.

37. Filosofskiy entsiklopedicheskiy slovar / sost. E. F. Gubskiy, G. V. Korableva, V. A. Lutchenko. - M.: INFRAM, 2000.-576 s.

38. Filosofiya: mislitelI, Ideyi, kontseptsiyi: PIdruchnik / V.

G. Kremen, V. V. Ilyin. - K.: Kniga, 2005. - 528 s.

39. Filosofskiy entsiklopedichniy slovnik / NAN Ukrayini, In-t fIlosofiyi Im. G. S. Skovorodi; redkol.: V. I. Shinkaruk (golova). - K.: Abris, 2002. - $742 \mathrm{~s}$.

40. Hasanov I. A. Vremya kak ob'ektivno-sub'ektivnyiy fenomen: slovar / I. A. Hasanov. - M.: Progress-Traditsiya, 2011. $-328 \mathrm{~s}$.

41. Chanyishev A. N. Filosofiya Drevnego mira: Ucheb. dlya vuzov / A. N. Chanyishev. - M.: Vyisshaya shkoka, 1999. $-703 \mathrm{~s}$.

\section{Boiko-Buzyl Yuliya Yuriivna}

Candidate of Psychology, Associate Professor, Doctoral student of Kharkiv National University of Internal Affairs, Kiev (Ukraine)

FORMATION AS A PHILOSOPHICAL AND PSYCHOLOGICAL CONCEPT

\section{ABSTRACT}

This article presents a theoretical analysis of «formation» as a philosophical and psychological concept. It is known that in philosophy of «formation» is tightly connected with «being», while in psychology it is tightly connected with «development». However, both these sciences recognize and value «formation» as an individual-specific phenomenon and concept.

It has been discovered that being is an objective reality, while formation is a continued possibility of being transformed into reality, where the inner goal of development is a potential itself (hidden possibilities, abilities, power for any activity that may appear under certain conditions). Development is a gradual movement of something with its further improvement, which makes this something stronger. Accordingly, formation is crystallization, emergence of something with its subsequent striking roots, when this something takes shape, that is, becomes a whole and in the best case becomes acme. Development is formation continued, since you cannot develop if you haven't occurred, haven't become something. Formation is the first step in the formation of any psychological phenomenon. It is the process of appearance of the phenomenon, progress of perfecting. Formation comes first, and then after a certain time it transforms into development. Formation creates a psychological phenomenon, strengthens it, forms its basics, and is like its foundation and internal source. Development continues this movement and gradually fills and improves this psychological phenomenon. 
Thus, based on the study of the inheritance of philosophical, psychological and pedagogical thoughts, the author's understanding of the formation as crystallization (transition) of potentials (possibilities) into a formalized whole (acme) is presented.

Key words: single, dispensable, being, development, formation.

\section{Бойко-Бузыль Юлия Юрьевна}

Кандидат психологических наук, дочент, докторант кафедры социологии и психологии факультета № 6 Харьковского национального университета внутренних дел, г. Киев (Украина)

\section{СТАНОВЛЕНИЕ КАК ФИЛОСОФСКОЕ И ПСИХОЛОГИЧЕСКОЕ ПОНЯТИЕ}

Аннотация. В статье представлен теоретический анализ категории «становление» как философского и психологического понятия. Установлено, что в философии «становления» неразрывно рассматривают с «бытием», в психологии - с «развитием». Однако общим является беспрекословное признание существования и ценности «становления» как индивидуально-особенного феномена и понятия.

Выявлено, что бытие - это объективно существующая реальность, а становление превращенная в действительность возможность бытия, где внутренней целью движения выступает сама потенция (скрытые возможности, способности, силы для какой-либо деятельности, которые могут проявиться при определенных условиях). Развитие - это поступательное движение чего-либо с последую- щим его совершенствованием, при котором это что-то приобретает силу и мощность. Соответственно, становления - это кристаллизация, возникновения чего-либо с последующим его укоренением, при котором это что-то приобретает вид и форму, то есть сформированное целое, и в лучшем своем проявлении становится акме. Развитие является продолжением становления, поскольку невозможно развиваться не возникнув, не явившись, то есть не ставши. Становление является первой ступенью образования любого психологического явления, процессом появления феномена, движением совершенствования. Сначала происходит становление, которое через некоторое время трансформируется в развитие. Становление зачинает психологическое явление, укрепляет его, закладывает основы, является как бы фундаментом, внутренним источником. А развитие подхватывает эту волну и постепенно насыщает, совершенствует данное психологическое явление.

Следовательно, на основе проведенного поискового рассмотрения наследия философской и психолого-педагогической мысли, представлено авторское понимание становления как кристаллизации (перехода) потенций (возможностей) в оформленное целое (акме).

Ключевые слова: общее, отличительное, бытие, развитие, становление.

Дата отримання статті: 19.06 .2017 Дата рекомендації до друку: 26.06.2017 